\title{
Witwatersrand seeks to defuse 'race row'
}

Cape Town. The University of the Witwatersrand last week agreed to lift a suspension it had imposed in December on its deputy vice-chancellor, William Makgoba, pending the results of a tribunal investigating allegations against him by 13 senior academics.

The suspension had followed Makgoba's decision to respond to the allegations including the charge that he had misled the university over details of his previous career as a research immunologist (see Nature 378, $324 ; 1995)$ - by releasing details of the personal files of his accusers to the press, in particular hinting at possible tax evasion.

In agreeing to lift the suspension, the university appears to be hoping to take some of the heat out of what has become a highly charged controversy that has given rise to charges of racism against a liberal academic community.

Makgoba - tipped as a leading contender to become the next vice-chancellor - has undertaken to return to Robert Charlton, the current vice-chancellor, all copies or extracts from the personal files of the academics who signed the letter of complaint against him, on the understanding that he would have access to the information in the context of any future university inquiry. He has also undertaken not to divulge confidential information outside the context of an inquiry.

Following a meeting last month with Charlton and Stephen Anderson, the chairman of the university's council, Sibusiso Bengu, South Africa's Minister of Education, had called for a "careful review" of Makgoba's suspension. The ruling African National Congress (ANC) had been less cautious, calling for Makgoba's immediate reinstatement and the use of mediation to address both sets of allegations.

At a meeting held on 12 December, the University of the Witwatersrand had responded by offering to lift Makgoba's suspension on conditions similar to those that he has now accepted, although they did not specify that he have access to the confidential information.

Makgoba initially rejected the universitiy's offer, and two members of the council, Nthato Motlana, chairman of the company New Africa Investments, and Aggrey Klaaste, the editor of the newspaper The Sowetan, walked out of the meeting, because, it is said, of the way the issue was being handled.

It now appears more likely that Makgoba will appear before the three-member com- mission. The third member of the tribunal will be Sir Colin Campbell, vice-chancellor of the UK University of Nottingham, who will join Lord Flowers and Walter Kamba, whose names were announced in late November.

Makgoba has said that he would only appear before a tribunal made up of individuals who were members of his own medical profession, and were his contemporaries. $\mathrm{He}$ demanded that they should also understand both his own background and the kind of transformation he claimed was needed at the university to meet the goals of postapartheid South Africa.

But Makgoba subsequently rejected an offer by the council to try to accommodate this demand by appointing additional members. He is now holding discussions with a member of the council, Mr Justice Fikile Bam, and it was in an effort to facilitate these discussions that the council last week agreed to lift Makgoba's suspension.

In addition to the three-member tribunal, a separate commission, which is likely to be headed by Malcolm Wallis, chairman of the Senior Council of the Bar of South Africa, will investigate Makgoba's allegations against the 13 members of staff.

Michael Cherry

\section{Congress steps back into dispute over Arizona telescope}

Washington. An Arizona congressman has come to the rescue of the embattled Mt Graham International Observatory in Arizona, proposing an amendment to a congressional budget bill that would allow construction to proceed on the Large Binocular Telescope (LBT), the focus of a bitter controversy that has pitted astronomers against environmentalists and Native American tribes.

But action on the 1996 appropriations bill for the Department of Interior is still being held up, as other amendments have been rejected by President Bill Clinton. And opponents of the telescope, which is being built by a team of partners headed by the University of Arizona, warn that passage of the Mt Graham "rider" would further inflame the long-standing controversy over the telescope.

The tersely worded amendment, proposed by Jim Kolbe (Republican, Arizona), states that an alternative site for the telescope on Mt Graham currently being considered conforms to a law passed by Congress in 1988 allowing the university to build an observatory on the mountain.

Such a clarification would allow construction work, blocked by court order since May 1994, to resume without the university having to conduct a new environmental impact statement (EIS) for the alternative site, which is 400 yards away from that which was originally proposed, as a local court has required it to do (see Nature 376, 719; 1995).

Opposition to the telescope originally focused primarily on its potential impact on the local population of the endangered red squirrel. But claims by the San Carlos Apache tribe that the mountain is sacred ground are rapidly becoming an even more contentious issue. Opponents of the telescope say that the mountain, called Dzil Nchaa Si'An by the Apaches, should be excluded from further development under the Native American Religious Freedom Act - a matter that would have to be addressed in a second EIS.

The Kolbe amendment sidesteps the requirement for an additional EIS. But this has only helped to inflame critics such as Peter Warshall, a former biologist at the University of Arizona and a leading antitelescope activist. Warshall says that if the amendment passes, "the anger level goes up tremendously, because the university [will have] avoided due process of law again".

Native American activists are also upset that Kolbe's rider was inserted as an alternative to an amendment to the Interior bill proposed by the Senate that would have required a study of ways to prevent HIV-AIDS trials to be carried out on Indian populations.

Administration officials are expected to sit down with congressional Republicans in the near future in an attempt to hammer out their differences over the Interior appropriations bill. So far, however, the White House has not raised specific objection to the provision covering the construction of the Mt Graham telescope, and supporters expect it to remain in the final bill.

Peter Strittmatter, of the university's Steward Observatory, says that the proposed amendment would "give us the go-ahead" to complete the \$80-million LBT, which still needs another partner to provide \$15 million towards its construction costs (the university is courting potential partners in Germany and the United States).

But the controversy over the telescope has become as much a culture clash - 'big astronomy' versus eco-warriors - as an argument over squirrels and religious freedom, and as such is unlikely to end either quickly or easily. Thus even if Kolbe's amendment passes, more challenges are inevitable, says John Fitzgerald, a Washington-based lawyer who represents the anti-telescope Mt Graham Coalition: "We are not out of options."

Tony Reichhardt 